JERZY JANCZEWSKI

Akademia Humanistyczno-Ekonomiczna w Łodzi, Polska - The University of Humanities and Economics in Lodz, Poland

\title{
Efektywne wykorzystanie zasobów jako czynnik konkurencyjności i przedsiębiorczości w usługach motoryzacyjnych
}

\author{
Efficient Use of Resources as a Factor of Competitiveness and Entrepreneurship in the \\ Automotive Services
}

Streszczenie: Artykuł prezentuje wybrane zagadnienia ponownego użycia części i zespołów samochodowych. Omówiono w nim sposoby wydłużania cyklu istnienia obiektu technicznego, zagadnienia bezpośredniego użycia części samochodowych i całych zespołów, regeneracji części i zespołów oraz odnowy całych samochodów. Działania takie zaliczono do działań przedsiębiorczych, wzmacniających konkurencyjność firm zajmujących się usługami motoryzacyjnymi. Przytoczono przykłady dwóch firm wywodzących się z lokalnego rynku i funkcjonujących w dziedzinie ponownego użycia oraz potwierdzono przypuszczenie, że wydłużanie cyklu życia części samochodowych i całych zespołów przysparza korzyści zarówno środowisku naturalnemu, jak i samym firmom, a także ich klientom.

\begin{abstract}
The article presents selected issues of the reuse of automotive parts and assemblies. The ways of extending the life cycle of a technical object, the issues of direct use of auto parts and entire system as well as the regeneration of parts and assemblies with health issues throughout the car have been described. Such activities are included into entrepreneurial activities, strengthening the competitiveness of companies in the automotive services. The examples of two companies originating from the local market and operating in the field of reuse were presented, which confirmed the assumption that extending the life cycle of car parts and systems gives an advantage to both the environment and the companies themselves as well as their clients.
\end{abstract}

Słowa kluczowe: cykl życia obiektu technicznego; części samochodowe; konkurencyjność; ponowne użycie; przedsiębiorczość

Key words: car parts; competitiveness; entrepreneurship; technical object life cycle; re-use

Otrzymano: 10 listopada 2015

Received: 10 November 2015

Zaakceptowano: 7 marca 2016

Accepted: 7 March 2016

\section{Sugerowana cytacja/Suggested citation:}

Janczewski, J. (2016). Efektywne wykorzystanie zasobów jako czynnik konkurencyjności i przedsiębiorczości w usługach motoryzacyjnych. Przedsiębiorczość - Edukacja, 12, 176-198. 
Wstęp

Nowoczesna koncepcja tworzenia przewagi konkurencyjnej kładzie szczególny nacisk na konieczność umiejętnego posługiwania się zasobami (Grzebyk, Kryński, 2011), a efektywne wykorzystanie szeroko rozumianych zasobów może być źródłem przewagi konkurencyjnej przedsiębiorstw, czynnikiem ich przedsiębiorczości i tworzenia nowych miejsc pracy. Wiąże się ono przede wszystkim z opracowaniem nowych produktów i usług, znalezieniem nowych sposobów ograniczania nakładów, minimalizacją liczby odpadów, poprawą zarządzania zapasami zasobów, zmianą modeli konsumpcji, optymalizacją procesów produkcyjnych oraz nowych metod zarządzania i prowadzenia działalności gospodarczej, a także metod ulepszających działania logistyczne ${ }^{1}$. Powodem do podejmowania takiej działalności jest ochrona środowiska oraz ochrona zasobów naturalnych.

Efektywne wykorzystanie zasobów dotyczące modeli konsumpcji to przede wszystkim umiejętne wykorzystanie zasobu pracy w posiadanych obiektach technicznych. Jednym z przykładów jest wydłużanie cyklu życia tych obiektów, co m.in. ma miejsce w branży motoryzacyjnej i jest realizowane na wiele sposobów, np. przez: ponowne bezpośrednie użycie, naprawę, odnowę, odbudowę, modyfikację, odrestaurowanie, kanibalizację bądź regenerację. Celem niniejszego artykułu jest prezentacja i analiza wybranych zagadnień ponownego użycia części i zespołów na przykładzie serwisowania i napraw pojazdów samochodowych oraz potwierdzenie hipotezy, że wydłużanie cyklu życia części samochodowych i całych zespołów przysparza korzyści zarówno środowisku naturalnemu, jak i samym firmom orazich klientom. Artykuł nawiązuje do zagadnień związanych z branżą motoryzacyjną, zarządzaniem logistyką zwrotną i małymi lokalnymi firmami usługowymi, które były poruszane w artykułach publikowanych przez autora we wcześniejszych numerach czasopisma „Przedsiębiorczość - Edukacja”. Wywody poparto przykładami dwóch firm zajmujących się ponownym użyciem samochodów i wywodzących się z lokalnego rynku usług. Szczegółowo omówiono sposoby wydłużania cyklu istnienia obiektu technicznego, zagadnienia bezpośredniego użycia części samochodowych i całych zespołów, regeneracji części i zespołów oraz zagadnienia dotyczące odnowy całych samochodów. Działania takie zaliczono do działań przedsiębiorczych, wzmacniających konkurencyjność firm zajmujących się usługami motoryzacyjnymi. Mogą one wskazywać kierunki dalszego rozwoju tych firm i rozprzestrzeniania się przedsiębiorczości w regionie.

\section{Branża motoryzacyjna w Polsce}

Branża motoryzacyjna w Polsce odgrywa istotną rolę w gospodarce. Stanowi ona 8,6\% naszej gospodarki i jest jedną z kluczowych gałęzi przemysłu. Oprócz szeroko rozumianej branży motoryzacyjnej funkcjonują liczne powiązane z nią sektory: usługi finansowe i biznesowe związane ze sprzedażą i utrzymaniem pojazdów, transport drogowy, produkcja i sprzedaż paliw samochodowych oraz budownictwo infrastruktury drogowej. W polskiej branży motoryzacyjnej przemysł oraz handel i usługi motoryzacyjne funkcjonują w znacznej mierze niezależnie od siebie. Przemysł motoryzacyjny nakierowany jest na eksport. Z kolei pojazdy oraz części i akcesoria sprzedawane na polskim rynku wtórnym pochodzą w większości z importu (Stan branży motoryzacyjnej..., 2013).

\footnotetext{
${ }^{1}$ Szerzej w: Europa efektywnie korzystająca z zasobów... (2011).
} 
Na polskim rynku motoryzacyjnym stale przybywa pojazdów samochodowych. Według danych Głównego Urzędu Statystycznego, na koniec 2014 r. w Polsce zarejestrowanych było 20 mln samochodów osobowych, czyli o ok. 3\% więcej niż rok wcześniej. Tym samym na 1000 mieszkańców przypadło 520 pojazdów, co oznacza, że statystycznie co drugi Polak ma samochód. W ślad za rosnącą liczbą samochodów idzie też ogromne zapotrzebowanie na części i akcesoria motoryzacyjne.

W Polsce funkcjonuje ponad 900 producentów części i akcesoriów motoryzacyjnych, z czego ok. 300 stanowią firmy z kapitałem zagranicznym. Z kolei dystrybucja części samochodowych odbywa się głównie przez warsztaty motoryzacyjne i sklepy. Dziennie do niezależnych serwisów i sklepów trafia średnio 640 tys. sztuk części. W naszym kraju działa ok. 620 punktów hurtowej sprzedaży produktów tego typu, blisko 18 tys. niezależnych warsztatów i ok. 1500 autoryzowanych serwisów. Sektor sprzedaży części motoryzacyjnych tworzy blisko 26,5 tys. miejsc pracy.

Zdecydowana większość warsztatów niezależnych i autoryzowanych wykonuje wszystkie rodzaje napraw, a zakres ich usług jest stale rozszerzany. Niektóre z warsztatów niezależnych specjalizują się w wąskiej dziedzinie, np. elektronice i elektryce, naprawach głównych silników lub blacharstwie i lakiernictwie. Serwisy autoryzowane współpracują z producentami i zajmują się konkretnymi markami samochodów. Serwisy autoryzowane prowadzą sprzedaż samochodów zarówno nowych, jak i używanych, zaś niektóre warsztaty niezależne zajmują się pośrednictwem i sprzedażą samochodów używanych.

Rocznie warsztaty niezależne notują ponad trzykrotnie więcej odwiedzin niż warsztaty autoryzowane. Przyczyn takiej dysproporcji jest kilka. Jedną z nich jest problem dostępności usług - poza dużymi miastami zwykle do autoryzowanego warsztatu jest bardzo daleko. Powodów atrakcyjności warsztatów niezależnych należy upatrywać również w niskim poziomie zamożności społeczeństwa, użytkowaniu wyeksploatowanych samochodów i tym samym chęci obniżania kosztów ich utrzymania. Rynek niezależny oferuje tańsze części (o ok. 60\%) oraz tańsze usługi (tu różnice sięgają nawet 100\%). Z tych też powodów udział warsztatów niezależnych w rynku części wynosi $60 \%$, mimo że warsztaty niezależne stanowią 92\% wszystkich punktów naprawy samochodów².

\section{Sposoby wydłużenia cyklu życia obiektu technicznego}

Cykl istnienia obiektu technicznego ${ }^{3}$ definiuje się jako czas od jego zaprojektowania (lub nawet od momentu sformułowania potrzeby, którą ów obiekt ma zaspokoić) przez jego wytworzenie i eksploatację aż do fizycznej likwidacji. Analizując cykl istnienia obiektu technicznego w perspektywie całkowitej odpowiedzialności producenta za wyrób, można mówić o cyklu otwartym i zamkniętym. Ten podział dotyczy nie tyle istnienia obiektu na rynku, ile problemu, co z nim zrobić po zakończeniu jego funkcjonowania, kiedy klient nie chce lub nie może go dalej eksploatować. W otwartym cyklu istnienia każdy wyrób wycofany z eksploatacji staje się odpadem trafiającym do recyklingu lub na składowisko odpadów komunalnych. W zamkniętym, czy raczej - rozszerzonym - cyklu obiekt techniczny zostaje usunięty z rynku

\footnotetext{
${ }^{2}$ Szerzej w: Branża motoryzacyjna w Polsce (2014); Jaka naprawdę jest branża motoryzacyjna w Polsce (2010); Włodarczyk, Janczewski (2014).

${ }^{3} \mathrm{~W}$ prezentowanej pracy za obiekt techniczny przyjęto pojazd samochodowy, a pojęcia: „cykl życia” i „cykl istnienia" traktowane są zamiennie.
} 
i zagospodarowany przez ponowne użycie, użycie jego części lub ponownie użycie pozyskanych z niego materiałów (Karwasz, 2010).

Wydłużenie cyklu życia obiektów technicznych może być realizowane na wiele sposobów, do których zalicza się: ponowne bezpośrednie użycie, naprawę, odnowę (odświeżenie, renowację), odbudowę, modyfikację, odrestaurowanie, kanibalizację i regenerację. Potencjalne sposoby wydłużenia cyklu istnienia części lub zespołów pojazdu samochodowego po zakończeniu ich użytkowania i wymontowaniu z samochodu pokazano na rycinie 1 . Sposoby te mogą dotyczyć nie tylko pojedynczych części i zespołów samochodowych, lecz także całego samochodu, zwłaszcza gdy po pewnym etapie użytkowania zmienia on właściciela i wymaga odpowiedniego przygotowania do dalszej eksploatacji.

Ryc. 1. Potencjalne sposoby wydłużenia cyklu istnienia części lub zespołu pojazdu samochodowego po zakończeniu użytkowania

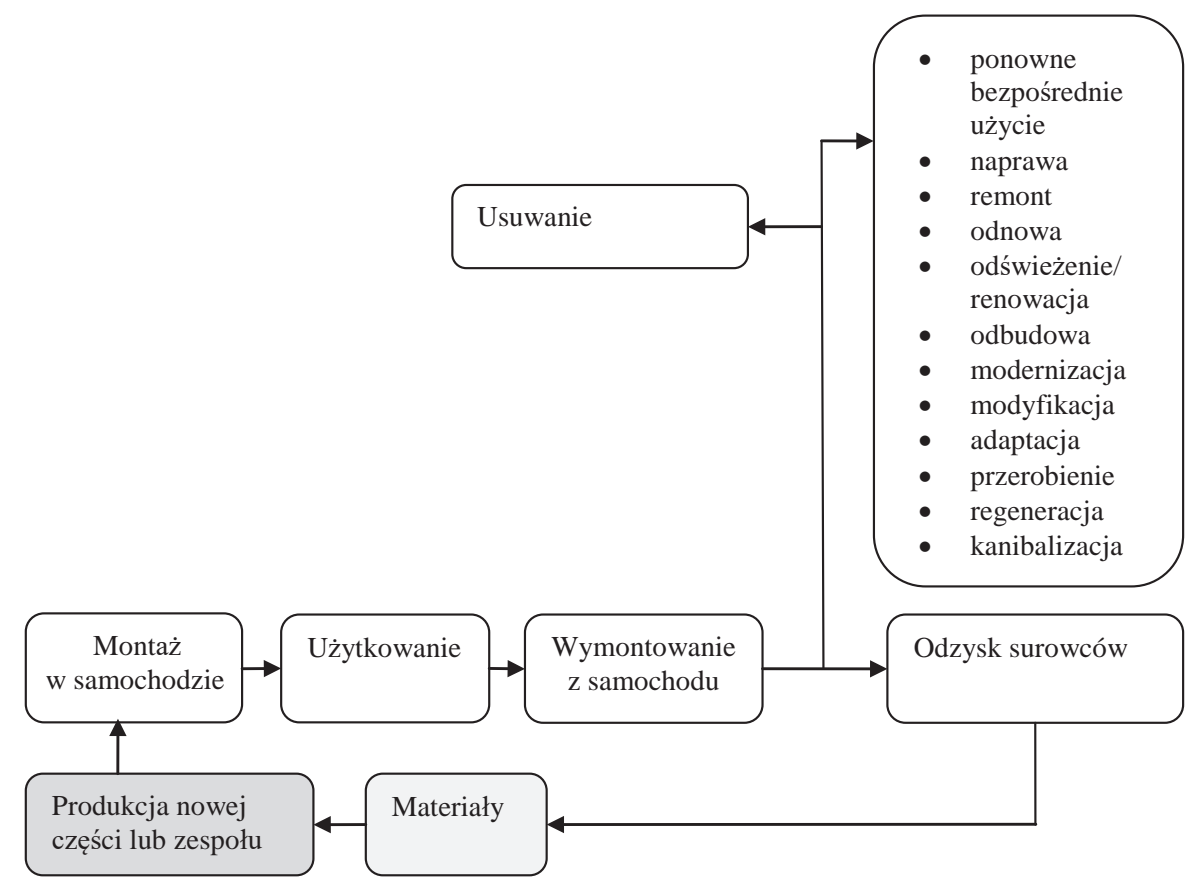

Źródło: opracowanie własne na podstawie Remanufacturing Terminology (2012: 4)

Ponowne bezpośrednie użycie jest najprostszą formą wydłużenia cyklu życia obiektu i występuje wtedy, kiedy obiekt ten lub jego zespoły i części (bez dodatkowych zabiegów), jedynie po oględzinach lub weryfikacji i stwierdzeniu ich przydatności do dalszego funkcjonowania, zostają kilkakrotnie wykorzystane w tym samym lub innym celu (Włodarczyk, Janczewski, 2013). Prawdopodobna jakość takich części w porównaniu z jakością części fabrycznych jest niższa lub w skrajnych wypadkach - porównywalna, np. gdy zespół lub części pochodzą z obiektu nowego, który z różnych względów uległ wycofaniu z eksploatacji. Jakość elementu przeznaczonego do ponownego bezpośredniego użycia ma ogromne znaczenie. Konsument, jeżeli napotka na informację o jakichkolwiek trudnościach w użytkowaniu takiego elementu, 
nie będzie chciał z niego skorzystać. Należy zaznaczyć, że niektórzy użytkownicy i firmy zajmujące się serwisem samochodów nie akceptują ponownego bezpośredniego użycia. Ci pierwsi prawdopodobnie z powodu braku pełnej gwarancji na zespół lub część rezygnują z nagrody finansowej, jaką niesie technologia ponownego użycia, a ci drudzy z powodu braku wypracowanych metod (jak należy w praktyce warsztatowej stosować tę technologię), utraty dodatkowej marży lub przekonania, że technologia ponownego użycia jest obarczona wysokim stopniem ryzyka.

Celem naprawy jest powrót sprawnego produktu z tym, że jakość naprawionych produktów jest prawdopodobnie niższa niż jakość oryginału. Naprawa wymaga demontażu i usunięcia usterek i ta operacja może być wykonana w dowolnym miejscu (Włodarczyk, Janczewski, 2013). O konieczności dokonania naprawy decydują te elementy, które osiągnęły maksymalne dopuszczalne zużycie lub uległy uszkodzeniu. Przy wykonywaniu napraw stwierdza się często, że w tym samym zespole część elementów musi być naprawiona bądź wymieniona, część zaś zachowała zdolność do dalszej pracy, a więc ma zapas czasu pracy, w końcu którego osiągnie dopiero maksymalną dopuszczalną wielkość zużycia.

Naprawy można podzielić na naprawy główne i naprawy eksploatacyjne. Posługując się przykładem pojazdu samochodowego, można powiedzieć, że naprawa główna ma za zadanie przywrócić zdolności do wykonania nowego pełnego przebiegu międzynaprawczego, określonego dla danego zespołu lub całego pojazdu. Natomiast naprawa eksploatacyjna przeprowadzona jest w okresie trwania przebiegu międzynaprawczego i ma za zadanie utrzymanie zdolności do kontynuowania tego przebiegu. Do napraw eksploatacyjnych zaliczane są również naprawy bieżące, polegające na wymianie lub naprawie tych elementów, które wcześniej od innych ulegają zużyciu lub uległy uszkodzeniu i powodują zakłócenia sprawności działania całego obiektu. Naprawa lub wymiana takich elementów nie powinna powodować konieczności całkowitej rozbiórki obiektu lub zespołu (Sobiepanek, Roehrych, Zienkiewicz, 1975).

W języku polskim synonimem wyrazu „naprawa” jest wyraz „remont”. Remont, podobnie jak naprawa, definiowany jest jako przywrócenie wartości użytkowej (funkcjonalności, sprawności techniczno-ekonomicznej) obiektu (maszyny, urządzenia, budynku). Należy jednak rozróżnić remont i naprawę, zwłaszcza gdy naprawa jest nieplanowana. W naprawie jakość produktu w porównaniu z jakością produktu fabrycznie nowego jest niższa, zaś w przypadku remontu jakość ta niekiedy może być równoważna (zob. tab. 1).

Odnowa, odświeżenie lub inaczej: renowacja ma na celu doprowadzenie używanego produktu do określonego poziomu jakości, który jest mniej rygorystyczny w stosunku do nowych produktów. W przypadku samochodu jest to przywracanie odpowiedniej jakości przez zabiegi estetyczne polegające na myciu, czyszczeniu, polerowaniu, malowaniu, chromowaniu, usuwaniu wgnieceń, rdzy, obcych zapachów i wiele innych. Czynności odnowy uwzględniają także technologiczną modernizację polegającą na zastępowaniu przestarzałych modułów i komponentów technologicznie lepszymi i nowocześniejszymi. W przypadku samochodu może dotyczyć to lakieru, silnika, tapicerki lub innych widocznych elementów.

$\mathrm{Z}$ odbudową mamy do czynienia w przypadku zniszczenia części widocznych obiektu technicznego, podczas gdy jego szkielet i zasadnicze elementy pozostają nienaruszone. W przypadku odbudowy obiekt techniczny częściowo nie istnieje. Może się zdarzyć, że jakaś jego część uległa uszkodzeniu i choć sam obiekt istnieje, to wymaga przeprowadzenia rozbiórki i odbudowy.

Odbudowa może dotyczyć także zespołów i ich elementów. W przypadku pojazdów samochodowych może ona dotyczyć samochodów powypadkowych z rozległymi uszkodzeniami 
karoserii, a także - przede wszystkim - modeli wyeksploatowanych charakteryzujących się niewielkim zasobem pracy. Odbudowa samochodu związana jest głównie z takimi działaniami, jak: czyszczenie pozostałości z korozji, wykonanie dodatkowych wzmocnień i uzupełnień konstrukcji, dopasowanie niektórych elementów oraz wszelkie prace blacharsko-lakiernicze i konserwacyjne. Szczególnie dużo czasu poświęca się tzw. dopracowaniu szczegółów.

$\mathrm{Z}$ ekonomicznego punktu widzenia odbudowa w porównaniu $\mathrm{z}$ wyprodukowaniem nowego samochodu jest nieopłacalna. W przypadku odbudowy prawdopodobna zmiana jakości $\mathrm{w}$ porównaniu z produktem fabrycznie nowym jest niższa lub równoznaczna, niekiedy możemy mieć do czynienia z wyższą jakością niż jakość produktu fabrycznie nowego (tab. 1).

Tab. 1. Sposoby wydłużenia cyklu życia w aspekcie możliwej zmiany jakości w porównaniu z produktem fabrycznie nowym

\begin{tabular}{|l|c|c|c|c|}
\hline \multirow{2}{*}{$\begin{array}{c}\text { Sposoby wydłużenia } \\
\text { cyklu życia }\end{array}$} & \multicolumn{4}{|c|}{$\begin{array}{c}\text { Możliwa zmiana jakości } \\
\text { w porównaniu z produktem fabrycznie nowym }\end{array}$} \\
\cline { 2 - 5 } & niższa & równoważna & wyższa & nieokreślona \\
\hline $\begin{array}{l}\text { Ponowne bezpośrednie } \\
\text { użycie }\end{array}$ & $\mathrm{X}$ & $\mathrm{X}$ & & \\
\hline $\begin{array}{l}\text { Naprawa } \\
\text { Remont }\end{array}$ & $\mathrm{X}$ & $\mathrm{X}$ & & \\
\hline Odnowa & $\mathrm{X}$ & $\mathrm{X}$ & & \\
Odświeżenie & $\mathrm{X}$ & & & \\
Renowacja & $\mathrm{X}$ & $\mathrm{X}$ & $\mathrm{X}$ & \\
\hline Odbudowa & $\mathrm{X}$ & $\mathrm{X}$ & $\mathrm{X}$ & \\
\hline Modernizacja & & $\mathrm{X}$ & $\mathrm{X}$ & \\
Modyfikacja & $\mathrm{X}$ & $\mathrm{X}$ & & \\
Adaptacja & $\mathrm{X}$ & $\mathrm{X}$ & $\mathrm{X}$ & \\
Przerobienie & & $\mathrm{X}$ & $\mathrm{X}$ & \\
\hline Regeneracja & $\mathrm{X}$ & $\mathrm{X}$ & $\mathrm{X}$ & \\
\hline Kanibalizacja & & $\mathrm{X}$ & \\
\hline Odrestaurowanie & & & \\
\hline
\end{tabular}

Źródło: opracowanie własne

Modernizacja to kolejny sposób wydłużania cyklu życia obiektów technicznych. Oznacza ona unowocześnienie lub uwspółcześnienie produktu, polegające na trwałym ulepszeniu, np. istniejącego obiektu technicznego, co prowadzi do zwiększenia jego wartości użytkowej. Modernizacja prowadzi do zmiany cech jakościowych na lepsze w stosunku do produktu fabrycznego i może mieć charakter kompleksowy lub cząstkowy. Modernizacja kompleksowa prowadzi do zmiany większości istotnych cech opisujących działanie obiektu technicznego. Gdy natomiast niektóre cele modernizacyjne realizowane w ramach modernizacji kompleksowej dotyczą zmian tylko niektórych niekorzystnych cech eksploatowanych obiektów, to jest to wówczas modernizacja niepełna cząstkowa (Woropay, 1996), zwana niekiedy modyfikacją.

Specyficzną formą modernizacji, jak pisze M. Woropay (1996), jest adaptacja oraz uproszczenie konstrukcji obiektu technicznego. Adaptacja obiektu jest taką modernizacją, która wynika ze zmiany technologii produkcji aktualnie wytwarzanego asortymentu wytworów. Zasadniczym celem adaptacji jest dokonanie takich zmian konstrukcyjnych, które umożliwią 
zarówno wykorzystanie obiektów technicznych do realizacji nowych zadań w systemach ich eksploatacji, jak i ich przekonstruowanie w przyszłości. Są to zwykle niewielkie zmiany konstrukcyjne, których zasadniczym celem nie jest unowocześnienie obiektów technicznych, lecz ich okresowe lub stałe przystosowanie do wykonywania określonych zadań produkcyjnych lub usługowych. Przykładem może być adaptacja samochodu osobowego do przewozu osób niepełnosprawnych, adaptacja samochodu ciężarowego do przewozu materiałów niebezpiecznych lub innego pojazdu samochodowego do wykonywania zadań specjalnych, takich jak ratownictwo drogowe.

Modernizacją jest również uproszczenie konstrukcji istniejących obiektów technicznych, niekiedy zwane przerobieniem. Rozwiązanie takie jest często bardziej opłacalne ekonomicznie w porównaniu z zakupem nowych specjalistycznych obiektów. Dokonując modernizacji przez uproszczenie konstrukcji, bierze się pod uwagę przyszły zakres ich wykorzystania.

Według definicji APRA (Automotive Parts Rebuilders Association - Stowarzyszenie Regenerujących Części Motoryzacyjne), termin „regeneracja” oznacza odbudowę używanej części pojazdu zgodnie z ogólnie przyjętymi zasadami sztuki inżynierskiej tak, że funkcjonalnie odpowiada ona części nowej. Zatem pod wyrazem „regeneracja” rozumiane jest działanie polegające na przywróceniu za pomocą odpowiednich zabiegów zużytym lub uszkodzonym częściom lub zespołom ich pierwotnych właściwości użytkowych, takich jak kształt, wymiary, parametry i pozostałe cechy niezbędne do ich dalszej, niezawodnej pracy. Podczas regeneracji wymontowana część/zespół (np. rozrusznik, alternator, przekładnia kierownicza), określana jako rdzeń, musi być całkowicie zdemontowana, oczyszczona i zbadana pod kątem zużycia i uszkodzenia. Zużyte, brakujące lub niefunkcjonujące składowe części są zamieniane na nowe lub odbudowane.

Wyrób regenerowany może być nawet jakościowo lepszy niż fabrycznie nowy, a tak się zdarza, gdy doświadczenia z regeneracji jednoznacznie wskazują na niedociągnięcia konstrukcyjno-technologiczne. Niedociągnięcia takie można wyeliminować np. przez zastosowanie nowych, ulepszonych materiałów, co znacznie wydłuża żywotność części i poprawia ich jakość w stosunku do części fabrycznie nowych (Remanufacturing Terminology, 2012).

Podejmowanie decyzji w zakresie regeneracji jest procesem bardzo złożonym ze względu na bardzo szeroki asortyment zespołów i części nadających się do regeneracji oraz różnorodność metod ich odnowy. Z uwagi na brak uniwersalnych metod regeneracji bardzo utrudniona jest typizacja regenerowanych części, co w konsekwencji może poważnie utrudnić osiągnięcie pożądanych efektów technicznych i ekonomicznych. Tomczyk przytacza szereg czynników mających bezpośredni wpływ na podjęcie właściwych (optymalnych) decyzji w zakresie regeneracji części wymiennych (Tomczyk, W: Włodarczyk, Janczewski, 2013).

Kanibalizacja czasami nazywana jest selektywnym demontażem i tym różni się od naprawy i renowacji, że tylko niewielka liczba zużytych produktów, które podlegają zwrotowi, pochodzi ze starego produktu i można ich użyć ponownie. Części te mogą być zarówno używane w naprawach i remontach, jak i w regeneracji. Jakość części zależy od procesu, w którym będą używane. Kanibalizacja może być również rozumiana jako proces polegający na pozyskiwaniu części zamiennych z uszkodzonych używanych maszyn i montowaniu ich w kolejnych, niekoniecznie podobnych maszynach. Celem tych sposobów zagospodarowania produktu jest zachowanie ich identyczności, natomiast w przypadku recyklingu tożsamość i funkcjonalność produktów i komponentów może być utracona (Włodarczyk, Janczewski, 2013).

Odrestaurowanie to zespół działań zmierzających do przywrócenia uszkodzonemu lub zmienionemu obiektowi technicznemu jego pierwotnej formy użytkowej. Prace 
restauratorskie przeprowadzane są na podstawie zachowanych materiałów archiwalnych w postaci planów, zdjęć itp. z użyciem oryginalnych detali i zachowaniem ocalałych fragmentów obiektów.

W przypadku pojazdów samochodowych odrestaurowanie może dotyczyć samochodów zabytkowych mających wartość historyczną lub sentymentalną, dla których zachowały się materiały archiwalne i ograniczona liczba oryginalnych zespołów lub części. W przypadku odrestaurowania prawdopodobna zmiana jakości w porównaniu z produktem fabrycznie nowym może być niższa, porównywalna lub niekiedy wyższa.

\section{Ponowne bezpośrednie użycie części i zespołów}

Części i używane zespoły oferowane są na niezależnym rynku motoryzacyjnym i stosowane przede wszystkim w naprawach samochodów o dużym przebiegu i niewielkiej wartości ekonomicznej. W Polsce większość takich samochodów użytkują transport indywidualny oraz mikrofirmy przewozowe.

Używane części i zespoły pochodzą z rozbiórki samochodów wycofanych z eksploatacji oraz rozbiórki samochodów importowanych z Anglii, z kierownicą po prawej stronie, przystosowanych do ruchu lewostronnego. W Polsce procederem rozbiórki samochodów zajmują się zarówno legalnie działające firmy, jak i szara strefa. Części używane są sprzedawane przeważnie na giełdach, bezpośrednio na złomowiskach oraz na stacjach demontażu pojazdów. Do niedawna podstawową formą sprzedaży części używanych był kontakt bezpośredni kupującego ze sprzedawcą. Obecnie najważniejszą rolę w handlu częściami używanymi odgrywają portale internetowe, np. Allegro, OLX, Auto Part i inne. Najwięksi dystrybutorzy części używanych mają tam wystawione tysiące opisów ze zdjęciami części zamiennych. Poziom zaawansowania takiej obsługi informatycznej jest relatywnie niski (brak zaawansowanych filtrów, brak możliwości wyboru części używanych przez numery katalogowe, nabywca przegląda wiele ofert). Dostawa części używanych do zamawiającego odbywa się najczęściej za pośrednictwem firmy kurierskiej. Zwykle nabywca opłaca koszty transportu części zamiennej (Gidlewski, Jemioł, Prochowski i in., 2015). Niekiedy zakupy używanych części i zespołów wiążą się z ryzykiem, zwłaszcza gdy nabywca nie ma możliwości organoleptycznej oceny zamawianego elementu i jedynie polega na informacji od sprzedającego. Zwykle sprzedawcy udzielają na wysyłane części lub zespoły krótkookresowej gwarancji, nazywanej potocznie gwarancją rozruchową. Gwarancja taka jest w praktyce trudna do wyegzekwowania, a zamiast zwrotu pieniędzy najczęściej oferowana jest wymiana wadliwego elementu na następny.

Używane zespoły i części można podzielić na dwie najważniejsze grupy. Do pierwszej z nich zalicza się części mechaniczne, a do drugiej - części blacharskie i inne tzw. części widoczne.

Części mechaniczne to przede wszystkim silniki, skrzynie biegów, amortyzatory, mosty napędowe, pompy wspomagania, kolumny kierownicze i sprężarki klimatyzacji. Części tych nie można ocenić organoleptycznie, a użytkownik ich sprawność poznaje dopiero po montażu w swoim samochodzie.

Części widoczne to przede wszystkim błotniki, drzwi, pokrywy, zderzaki, fotele, klamki, reflektory i lampy. W przypadku takich elementów ryzyko zakupu jest niewielkie i w większości przypadków użycie w naprawie części widocznej jest korzystniejszym rozwiązaniem niż zastosowanie nowego zamiennika. 


\section{Regeneracja części i zespołów w motoryzacji}

Części i zespoły regenerowane fabrycznie są oferowane na niezależnym rynku motoryzacyjnym i również stosowane przez koncerny samochodowe do napraw samochodów w serwisach autoryzowanych przez producentów. Za regenerowaniem części zamiennych przemawiają względy ekonomiczne. Regeneracja ma również wymiar ekologiczny, tj. ochronę i dbałość o środowisko. Do najczęściej regenerowanych podzespołów montowanych w samochodach należą: rozruszniki, alternatory, półosie napędowe, sprzęgła, przekładnie kierownicze, zaciski hamulcowe, silniki i elementy silników, bloki silników, głowice silników, wtryskiwacze, koła zamachowe, pompy wtryskowe, turbosprężarki, filtry cząstek stałych, chłodnice, sprężarki klimatyzacji, kompletne sprzęgła, skrzynie biegów manualne i automatyczne, pompy wspomagania układu kierowniczego.

W latach minionych regeneracją części w Polsce zajmowali się głównie rzemieślnicy i niewielkie firmy. Obecnie regeneracją części samochodowych zajmują się również wielkie koncerny, w tym producenci samochodów oraz producenci i dyspozytorzy części. W naszym kraju przybywa firm zajmujących się regeneracją części samochodowych, a coraz częstsze i większe inwestycje zagraniczne dokonywane są przez zachodnie firmy regeneracyjne.

Producenci samochodów coraz częściej decydują się na wprowadzenie do swojej oferty części regenerowanych m.in. z obawy utraty klientów stacji serwisowych, po tym jak unijne przepisy zaczęły liberalizować rynek motoryzacyjny, a Dyrektywa GVO umożliwiała serwisowanie samochodów w niezależnych warsztatach i ich naprawę za pomocą zamienników bez utraty gwarancji. Regenerowane podzespoły są zatem traktowane jako alternatywa dla stosowania tańszych zamienników (Włodarczyk, Janczewski, 2013).

Na rynku polskim regenerowane części zamienne oferuje większość serwisów autoryzowanych. Serwisy te sprzedają tańsze części zamienne po regeneracji pod warunkiem zwrotu zużytego elementu lub zapłaty kaucji. Na produkt po regeneracji przysługuje taka sama gwarancja jak na produkt nowy.

\section{Odnowa obiektów technicznych w motoryzacji}

W Polsce intensywnie rozwija się rynek samochodów używanych. Na dużą skalę oferują je importerzy, firmy leasingowe i floty samochodów. Również małe firmy i indywidualni użytkownicy stosunkowo często podejmują decyzje o sprzedaży lub zamianie dotychczas używanego samochodu na nowszy model lub model pełniej zaspakajający ich potrzeby. Większość z tych pojazdów wymaga odnowy, która zwykle nie ogranicza się do takich prostych zabiegów, jak mycie, czyszczenie czy odkurzanie.

Równolegle z rozwojem rynku samochodów używanych powiększa się liczba firm oferujących liczne usługi oparte na profesjonalnych procesach odnowy. Wymownym przykładem mogą być firmy zajmujące się usługami z wykorzystaniem technologii Smart czy PDR lub usługami zaawansowanej kosmetyki samochodowej, tzw. auto detailingiem.

Usługi z użyciem technologii Smart, tzw. Smart Repairs (Small - Medium Area Repair Technology) dotyczą drobnych uszkodzeń elementów pojazdów, np. uszkodzeń niewielkich powierzchni szyby, tapicerki, karoserii, obręczy kół i innych. Popularne działania w tej technologii to wykonywanie naprawy zderzaków, listew ochronnych, zapraw lakierniczych, naprawy wgnieceń bez lakierowania, naprawy szyb klejonych, tapicerki welurowej, winylowej, 
materiałowej i skórzanej, odnowa obręczy kół, spawanie elementów z tworzyw sztucznych (Smart Repair - szybkie naprawy, 2015).

Usługi bezinwazyjnego usuwania wgnieceń średnich i małych powierzchni z karoserii pojazdów wykonywane są z użyciem technologii zwanej PRT (Paintless Dent Removal) polegającej na usuwaniu wgnieceń karoserii samochodowych bez konieczności późniejszego lakierowania (What is PDR?, 2015).

Naprawy drobnych uszkodzeń obejmujących niewielkie powierzchnie samochodu pozwalają zachować oryginalność jego elementów i części oraz znacznie skracają czas naprawy w stosunku do technologii tradycyjnej, zatem również pozwalają obniżyć cenę takiej naprawy.

Angielski termin „auto detailing” nie ma w języku polskim odpowiednika. Pojęcie to definiuje się jako zoptymalizowany proces kompleksowego czyszczenia, renowacji i konserwacji pojazdu samochodowego lub jego elementów, zarówno na zewnątrz, jak i wewnątrz, w celu podniesienia walorów estetycznych i użytkowych pojazdu, a także przedłużenia jego żywotności (Auto detailing, 2015).

Auto detailing wnętrza obejmuje czyszczenie, regenerację i konserwację przestrzeni pasażerskiej oraz bagażnika. Główne procesy dokonywane podczas auto detailingu polegają na czyszczeniu elementów tapicerskich, podsufitki, kokpitu, wszelkich elementów plastikowych i metalowych. Nacisk kładziony jest na odnowę najdrobniejszych szczegółów i przywrócenie stanu fabrycznego.

Auto detailing zewnętrzny obejmuje regenerację i konserwację powłoki lakierniczej, kół, szyb, elementów chromowanych. W przypadku regeneracji powłoki lakierniczej proces ten można podzielić na takie etapy, jak:

- oczyszczenie karoserii, które prowadzi do usunięcia wszelkich obcych cząsteczek z powierzchni zewnętrznych,

- polerowanie powłoki lakierniczej, które może być dokonywane ręcznie lub maszynowo,

- konserwację, która polega na nałożeniu ochronnej warstwy wosku.

Auto detailing jest pewnym przewrotem w kosmetyce samochodowej. W odróżnieniu od oferty myjni samochodowych celem auto detailingu nie jest utrzymanie standardowej czystości, a podniesienie walorów estetycznych i użytkowych pojazdów. Technologie stosowane w firmach trudniących się auto detalingiem pozwalają na usunięcie większości śladów dotychczasowej eksploatacji, przedłużają cykl istnienia, zwiększając wartość rynkową pojazdu, co również wspomaga jego sprzedaż (Kosmetyka samochodowa..., 2015).

\section{Studium przypadku}

\section{Przedsiębiorstwo „Handel artykułami przemysłowymi i częściami samochodowymi”}

Prezentowane przedsiębiorstwo powstało w 2000 r. jako firma osoby cywilnej zajmującej się transportem i specjalizującej się w usługach pomocy drogowej dla pojazdów ciężarowych i dostawczych ${ }^{4}$. Mieści się ono w województwie wielkopolskim, na szlaku pomiędzy Łodzią a Poznaniem. Początkowo usługi pomocy drogowej wykonywane były przez przedsiębiorstwo na obszarze Polski. Obecnie firma świadczy swoje usługi w całej Unii Europejskiej, a także poza Unią. Początki działalności z powodu małej liczby klientów były dla firmy trudne, lecz z biegiem czasu liczba klientów wzrastała, a firma dodatkowo zajęła się skupem i importem

\footnotetext{
${ }^{4}$ Informacje o firmie pochodzą z inżynierskiej pracy dyplomowej Michała Marka Zaręby, napisanej pod kierunkiem autora artykułu.
} 
wycofanych z eksploatacji samochodów ciężarowych i dostawczych, natomiast później ich demontażem i sprzedażą używanych zespołów oraz części. W tym celu poszerzono powierzchnię magazynową firmy, zwiększono plac dla samochodów, wybudowano magazyny i biuro obsługi klientów, jak również zakupiono niezbędny sprzęt, taki jak specjalne dźwigi do wyciągania i ładowania silników samochodowych, wózki widłowe do przewozu zdemontowanych części i podzespołów itp. Wraz z rozwojem firmy powiększyła się kadra pracownicza, zainwestowano też w obsługę informatyczną. Zatrudniono menedżera, księgową, zwiększono liczbę pracowników, a także zakupiono sprzęt komputerowy oraz niezbędne programy do zarządzania przedsiębiorstwem. W 2009 r. firma powiększyła zakres usług o złomowanie samochodów osobowych i obecnie jest jedną z większych w swoim rejonie firm świadczących usługi złomowania i sprzedaży części.

Obecnie w ofercie przedsiębiorstwa znajdują się takie usługi, jak: transport krajowy i zagraniczny pojazdów, skup pojazdów powypadkowych, złomowanie pojazdów, naprawa i sprzedaż samochodów ciężarowych i dostawczych oraz sprzedaż części. Firma ma bardzo duży asortyment używanych części i zespołów do takich marek, jak: MAN, Mercedes, Iveco, Daf, Scania, Renault, Volvo. Oferowane zespoły i części to m.in. skrzynie biegów, silniki, ogumienie, obręcze kól, kompletne kabiny, reflektory, szyby, deski rozdzielcze, fotele, obicia, elementy blacharki i elementy podwozi.

Sprzedaż detaliczna i hurtowa prowadzona jest na miejscu w firmie przez kontakt indywidualny, jak również wysyłkowo przy współpracy z firma kurierską. Informacja o dostępnych częściach wraz z ich szczegółowym opisem znajduje się na stronie internetowej firmy. Firma korzysta z różnego rodzaju aukcji, oferuje części za pośrednictwem Allegro i Otomoto, ogłasza się w prasie branżowej i ma stoiska na giełdach samochodowych. Przedsiębiorstwo jest otwarte na wszystkich klientów zarówno instytucjonalnych, jak i indywidualnych. Udziela fachowej pomocy i porad technicznych, traktując każdego klienta indywidualnie.

Przedsiębiorstwo ma dobrą opinię wśród klientów i sprzyjające warunki rynkowe, które przejawiają się stale rosnącym popytem na używane części i zespoły do samochodów ciężarowych oraz dostawczych. Czynnikami konkurencyjności przedsiębiorstwa są: lokalizacja przedsiębiorstwa, wykwalifikowana kadra, właściwe relacje z partnerami zagranicznymi, niższa niż u konkurencji cena połączona z upustami, odpowiednia jakość części i zespołów, terminowość dostaw, własny transport do klienta, a także gwarancja na zakupioną część wraz z fakturą VAT. Należy także wspomnieć o przedsiębiorczości firmy będącej rezultatem takich jej czynników, jak kreatywność właściciela i jej pracowników, kalkulowanie i nieunikanie ryzyka oraz umiejętność szybkiego reagowania na potrzeby klientów.

\section{Przedsiębiorstwo Luk-Car}

Przedsiębiorstwo Luk-Car funkcjonuje na rynku usług motoryzacyjnych od 30 lat i specjalizuje się w usługach lakierniczo-blacharskich ${ }^{5}$. Firma obsługuje rynek wtórny pojazdów samochodowych, przygotowując je do ponownego użytkowania i sprzedaży. Przedsiębiorstwo zaliczane jest do grupy warsztatów niezależnych i kontynuuje rodzinne tradycje. Obecnie prowadzone jest w drugim pokoleniu.

W pierwszym pokoleniu obszarem działań przedsiębiorstwa był rynek lokalny w województwie małopolskim, a usługi ograniczały się do drobnych napraw blacharsko-lakierniczych

\footnotetext{
${ }^{5}$ Informacje o formie Luk-Car pochodzą z inżynierskiej pracy dyplomowej Jakuba Skąpskiego, napisanej pod kierunkiem autora artykułu.
} 
pojedynczych elementów nadwozia. Była to wtedy jednoosobowa firma o niewielkim dochodzie netto, nieprzekraczającym miesięcznie $1500 \mathrm{zł}$.

Przyrost samochodów w Polsce i import używanych samochodów zainspirował nowego właściciela do rozwoju firmy. W ciągu trzech lat (2009-2012) zakupiono komorę lakierniczą wraz z urządzeniami grzewczymi i systemem wentylacji i oświetlenia, sprzęt do polerowania, szlifowania, matowania powłok lakierniczych, myjkę ciśnieniową i odkurzacz piorący. Równocześnie przedsiębiorstwo pozyskało klientów zajmujących się importem powypadkowych samochodów osobowych głównie z Austrii, Niemiec i Francji. Wraz ze wzrostem liczby klientów powiększono plac parkingowy, rozbudowano bramę wjazdową, umożliwiającą wjeżdżanie dużych zestawów lawet, zakupiono urządzenia emitujące światło podczerwone suszące lakier w przeciągu 30 minut. W niedalekiej przyszłości firma planuje uruchomić mieszalnię lakierów i wdrożyć nowe technologie, takie jak Smart i PDR.

Sukcesywnie zatrudniano nowych pracowników - początkowo na umowę o dzieło, później na umowę o pracę. Obecnie na stałe firma zatrudnia czterech pracowników. W 2014 r. firma zrealizowała ok. 550 zleceń na usługi blacharsko-lakiernicze, przy czym większość z nich dotyczyła samochodów powypadkowych o różnym stopniu uszkodzenia, pochodzących zarówno od klientów indywidualnych, jak i instytucjonalnych. Znaczna część samochodów była przeznaczona do dalszej odsprzedaży, w niektórych dokonano modernizacji i przeróbki np. dla potrzeb miejscowej jednostki straży pożarnej, niektóre z odnowionych samochodów ponownie wróciły na zachodni rynek.

Najpopularniejsze marki samochodów, którymi firma się zajmuje, to Nissan Qashqai, Hiundai ix35, Kia Sportage, Mazda 2 oraz 3. Marki te są tańsze niż marki niemieckie, a jednocześnie równie niezawodne. Najczęstsze roczniki naprawianych w Luk-Car samochodów należą do przedziału 2009-2013 i mają szacunkowy przebieg ok. 3000 km. Średnia wartość rynkowa naprawianego pojazdu waha się w granicach $40-80$ tys. zł (zdarzają się też samochody o wartości ok. 120 tys. zł). Stąd kolejną inwestycją przedsiębiorstwa był monitoring, pozwalający obserwować cały plac, na którym przeważnie znajduje się ok. 20 samochodów.

Obok rozwoju ilościowego firma zwraca szczególną uwagę na rozwój jakościowy i bezpieczeństwo zarówno w aspekcie bezpieczeństwa ruchu drogowego, jak i bezpieczeństwa ekologicznego. Czynnikami konkurencyjności Luk-Car są: wyposażenie firmy, wykwalifikowana i stabilna kadra, współpraca w ramach sieci z importerami i sprzedawcami samochodów, dobra reputacja i kreatywność właściciela oraz pracowników, a także ich zapał do pracy wspomagany satysfakcjonującą nagrodą finansową.

\section{Podsumowanie}

Światowe trendy ukierunkowane na efektywną gospodarkę zasobami dotyczą każdego ogniwa łańcucha dostaw, w tym i łańcuchów powrotnych. Małe lokalne firmy zajmujące się usługami motoryzacyjnymi mogą w łańcuchach powrotnych upatrywać szansy na rozwój i sukces. Przedsiębiorstwa świadczące usługi motoryzacyjne nie muszą wyłącznie zaspokajać potrzeb rynku lokalnego, gdyż w dobie powszechnej globalizacji, rozwoju nowych technik komunikacji, swobodnego przepływu informacji, usług i produktów mogą również współpracować z klientami spoza rynku lokalnego, czego wymownym dowodem są dwa przykłady małych firm zaprezentowanych w niniejszym artykule. 
Działaniami związanymi z wydłużaniem cyklu istnienia zespołów lub części zainteresowani są nie tylko użytkownicy samochodów, lecz także ich producenci. Pojedyncze części lub całe zespoły samochodu niejednokrotnie wykonane są z surowców deficytowych, pochodzących ze źródeł nieodnawialnych. Stąd wydłużanie cyklu życia nabiera dużego znaczenia, a działania firm w tym obszarze przysparzają dodatkowych korzyści zarówno środowisku naturalnemu, jak i samym firmom i ich klientom.

\section{Literatura}

\section{Referencess}

Auto detailing. (2015, 2 września). Pozyskano z: https://pl.wikipedia.org/wiki/Auto_detailing

Europa efektywnie korzystająca z zasobów - inicjatywa przewodnia strategii „Europa 2020”. (2015, 2 września). Bruksela: Komisja Europejska. Pozyskano z: http://www.mg.gov.pl/files/upload/8418/ resource-efficient_europe_pl.pdf

Gidlewski, M., Jemioł, L., Prochowski, L., Tkaczuk, S., Sklorz, A.R. (2015). Analiza polskiego rynku części zamiennych do napraw samochodów. Warszawa: Przemysłowy Instytut Motoryzacji, Centrum Rzeczoznawstwa Samochodowego i Szkoleń.

Grzebyk, M., Kryński, Z. (2011). Konkurencja i konkurencyjność przedsiębiorstw. Ujęcie teoretyczne. W: M.G. Woźniak N., Fedan (red.), Nierówności społeczne a wzrost gospodarczy. Uwarunkowania sprawnego działania w przedsiębiorstwie i regionie, 20, Uniwersytet Rzeszowski, Katedra Teorii Ekonomii i Stosunków Międzynarodowych, Katedra Ekonomiki i Zarządzania, Rzeszów: Wydawnictwo Uniwersytetu Rzeszowskiego, 107-117.

Jaka naprawdę jest branża motoryzacyjna w Polsce. (2010). Warszawa: Stowarzyszenie Dystrybutorów i Części Motoryzacyjnych.

Karwasz, A. (2015, 2 września). Ocena recyklingowa wyrobów. Innowacje w Zarządzaniu i Inżynierii Produkcji. PTZP, 622-628. Pozyskano z: http://www.ptzp.org.pl/files/konferencje/kzz/artyk_ pdf_2010/73_Karwasz_A.pdf

Kosmetyka samochodowa (auto detailing) - odświeżanie auta. (2015, 2 września). Pozyskano z: http:// www.s-plus.pl/kosmetyka-auto-detailing

Raport Branży Motoryzacyjnej. (2015, 2 września). Polski Związek Motoryzacyjny. Pozyskano z: http:// www.pzpm.org.pl/Rynek-motoryzacyjny/Roczniki-i-raporty/Raport-branzy-motoryzacyjnej-2015

Remanufacturing Terminology Remanufacturing Term Guideline. (2015, 2 września). APRA Europe. Pozyskano z: http://www.apra-europe.org/main.php?target=remanufacturing

Smart Repair - szybkie naprawy. (2015, 2 września). Pozyskano z: http://www.s-plus.pl/naprawa-smart-repair

Skąpski, J. (2014). Procesy przygotowania samochodów do ponownego ich użycia na przykładzie firmy Luk-Car. Łódź: Akademia Humanistyczno-Ekonomiczna. Inżynierska praca dyplomowa, materiał niepublikowany.

Stan branży motoryzacyjnej oraz jej rola w polskiej gospodarce. (2013; 2015, 2 września). Raport KPMG w Polsce z inicjatywy Polskiego Związku Motoryzacyjnego. Pozyskano z: https://www. kpmg.com/PL/pl/IssuesAndInsights/ArticlesPublications/Documents/mobile/Stan-branzymotoryzacyjnej-2013.pdf

Sobiepanek, T., Roehrych, K., Zienkiewicz, J. (red.). (1975). Studium w zakresie podwyższania trwałości elementów maszyn. Poradnik III. Warszawa: Ośrodek Doskonalenia Kadr SIMP.

What is PDR?. (2015, 2 września). Pozyskano z: http://napdrt.org/for-consumers/about-paintless-dentrepair/

Włodarczyk, M., Janczewski, J. (2013). Zarządzanie logistyką zwrotną w usługach motoryzacyjnych. Przedsiębiorczość - Edukacja, 9, 187-203. 
Włodarczyk, M., Janczewski, J. (2014). Uwarunkowania rozwoju przedsiębiorczości w Polsce w branży motoryzacyjnej. Przedsiębiorczość - Edukacja, 10, 94-108.

Woropay, M. (red.). (1996). Podstawy racjonalnej eksploatacji maszyn. Bydgoszcz - Radom: Akademia Techniczna i Instytut Technologii Eksploatacji.

Zaręba, M.J. (2014). Procesy logistyczne w przedsiębiorstwie złomowania pojazdów ciężarowych. Łódź: Akademia Humanistyczno-Ekonomiczna. Inżynierska praca dyplomowa, materiał niepublikowany.

Jerzy Janczewski, dr inż., adiunkt, Akademia Humanistyczno-Ekonomiczna, Katedra Systemów Transportowych. Jerzy Janczewski jest inżynierem mechanikiem, doktorem nauk ekonomicznych w zakresie zarządzania. Jego zainteresowania badawcze koncentrują się na logistyce zwrotnej i problematyce zarządzania przedsiębiorstwami mikro i małymi z branży usług motoryzacyjnych i transportu drogowego.

Jerzy Janczewski, Engineer, lecturer, University of Humanities and Economics, Transport Systems Department. Mechanical engineer, doctor of economic sciences in management. Research interests focus on reverse logistics and management issues of micro and small enterprises in the industry of automotive service and road transport.

\section{Adres/Address:}

Akademia Humanistyczno-Ekonomiczna

Katedra Systemów Transportowych

ul. Rewolucji $1905 \mathrm{nr} 64$

90-222 Łódź, Polska

e-mail: jerzyjanczewski@poczta.onet.pl 